\title{
High T3 Syndrome Associated with Metastatic Papillary and Poorly Differentiated Thyroid Cancer
}

\author{
Run Yu, MD, PhD
}

Division of Endocrinology, UCLA David Geffen School of Medicine, Los Angeles, CA. runyu@mednet.ucla.edu

*Corresponding Author: Dr. Run Yu, MD, PhD, Division of Endocrinology, UCLA David Geffen School of Medicine, Los Angeles, CA.

\section{Abstract}

Circulating levels of free thyroxine (T4) and triiodothyronine (T3) are tightly regulated by thyrotropin (TSH) via deiodinases. Free T4 and T3 levels are usually congruent but may become discordant when deiodinase activities are altered by diseases or medications. High T3 syndrome is seen in hyperthyroidism, Allan-HerndonDudley syndrome, and massive metastatic follicular thyroid cancer (FTC), where the T4-to-T3 conversion is increased (1-3). High T3 syndrome has not been reported in metastatic papillary thyroid cancer (PTC) or poorly differentiated thyroid cancer (PDTC). Described here is the first case of high T3 syndrome in a patient with a large metastatic burden of PTC and PDTC.

\section{INTRODUCTION}

Circulating levels of free thyroxine (T4) and triiodothyronine (T3) are tightly regulated by thyrotropin (TSH) via deiodinases (1). Free T4 andT3 levels are usually congruent but may become discordant when deiodinase activities are altered by diseases or medications. Low T3 syndrome is a well-known condition where the T4-to-T3 conversion is inhibited by critical illness; high T3 syndrome is seen in hyperthyroidism,Allan-Herndon-Dudley syndrome, and massive metastatic follicular thyroid cancer (FTC), where the T4-to-T3 conversion is increased(1-3). Described here is a case of high T3 syndrome in metastatic papillary and poorly differentiated thyroid cancer (PTC and PDTC).

\section{CASE REPORT}

A 60-year-old male presented for treatment of metastatic thyroid cancer. At age 30, he was found to have a goiter by physical examination and was given levothyroxine (LT4) $25 \mathrm{mcg}$ daily. At age 54, CT urogram (for hematuria) incidentally found a 1.8 $\mathrm{cm}$ expansile lytic lesion on the right 9th rib; bone scan showed high signal at the location; he did not follow up as recommended. At age 60, he felt 2 large masses, one on the back of head and the other on the right chest wall. The masses were biopsied and their histology and immunochemical profile were consistent with metastatic PTC and PDTC, respectively. Thyroid ultrasound confirmed multinodular goiter. FDG PET/CT showed a large lytic lesion in occipital bone, $5.5 \times 4.6 \mathrm{~cm}$, a right lytic rib mass $7 \times 9.5 \mathrm{~cm}$, and numerous other lytic lesions in ribs, sternum, and right ischium. He underwent total thyroidectomy. Histologically, the left lobe contained a 1.9-cm PTC, follicular variant; the right lobe contained a $3.8-\mathrm{cm}$ PDTC with a $20 \%$ component of follicular variant of PTC. Postoperatively, he started LT4 replacement (Table 1). A few days after thyroidectomy, the patient developed aspiration pneumonia, cardiac arrest, pleural effusions, and acute kidney injury. He was intubated and required tracheostomy, percutaneous endoscopic gastrostomy, and thoracentesis. He stayed in ICU for 3 weeks. His condition gradually improved and 4 weeks after thyroidectomy, he was discharged with tracheostomy and gastrostomy tubes. His conditions continued to improve; the tracheostomy and gastrostomy tubes were removed several months after discharge. One year after thyroidectomy, he received radioactive iodine ablation (RAI). Post-RAI scan showed iodine-avid lymph nodes in the anterior cervical and supraclavicular regions and multiple chest wall soft tissue lesions with low iodine avidity.

Only after RAI, did it become evident that his thyroid 
function test results were very unusual (Table 1). For example, 1 month after RAI, while taking LT4 100 mcg daily, his TSH level was $3.5 \mathrm{mIU} / \mathrm{L}$ (normal 0.34.7) and free T4 $0.6 \mathrm{ng} / \mathrm{dL}(0.8-1.6) ; 3$ months after RAI, TSH was $0.21 \mathrm{mIU} / \mathrm{L}$ and free T4 $0.7 \mathrm{ng} / \mathrm{dL}$. He never took liothyronine and he appeared grossly healthy after RAI; the post-RAI scan did not show brain up take. Thyrotroph deficiency was deemed very unlikely; abnormal metabolism of LT4 was suspected. Free T3 and reverse T3 were measured in the same blood specimen drawn 3 months after RAI and free T3 was elevated while reverse T3 suppressed (Table1).
In retrospect, nearly 5 months before thyroidectomy, free T4 was already low with concomitant high normal free T3 and normal TSH. Before thyroidectomy, free T4 index was also low while he was clinically euthyroid. He was ultimately diagnosed with high T3 syndrome associated with metastatic thyroid cancer. His thyroid function test results during ICU stay were probably due to 3 concurrent conditions: high T3 syndrome, low T3 syndrome, and poor LT4 absorption. Because high T3 syndrome was not recognized when he was in ICU, the LT4 dose was increased, resulting in complete suppression of TSH (Table 1)

\begin{tabular}{|c|c|c|c|c|c|c|}
\hline & $\begin{array}{c}141 \text { days } \\
\text { before total } \\
\text { thyroidectomy }\end{array}$ & $\begin{array}{c}6 \text { days } \\
\text { before total } \\
\text { thyroidectomy }\end{array}$ & $\begin{array}{l}23 \text { days after } \\
\text { total } \\
\text { thyroidectomy } \\
\text { (in ICU, } \\
\text { after cardiac } \\
\text { arrest, pleural } \\
\text { effsuion, and } \\
\text { tracheostomy) }\end{array}$ & $\begin{array}{c}52 \text { days } \\
\text { after total } \\
\text { thyroidectomy } \\
\text { (3 days after } \\
\text { discharge in } \\
\text { stable condition) }\end{array}$ & $\begin{array}{c}398 \text { days } \\
\text { after total } \\
\text { thyroidectomy, } \\
33 \text { days afetr } \\
\text { RAI }\end{array}$ & $\begin{array}{c}459 \text { days } \\
\text { after total } \\
\text { thyroidectomy, } \\
94 \text { days after } \\
\text { RAI }\end{array}$ \\
\hline $\begin{array}{l}\text { Daily thyroid } \\
\text { replacement }\end{array}$ & $\begin{array}{l}\text { LT4, } 25 \mathrm{mcg} \text {, } \\
\text { orally }\end{array}$ & $\begin{array}{l}\text { LT4, } 25 \mathrm{mcg} \text {, } \\
\text { orally }\end{array}$ & $\begin{array}{l}\text { LT4, } 137 \mathrm{mcg} \text {, } \\
\text { per nasogastric } \\
\text { tube }\end{array}$ & $\begin{array}{l}\text { LT4, } 175 \text { mcg, per } \\
\text { gastric tube }\end{array}$ & $\begin{array}{l}\text { LT4, } 100 \mathrm{mcg} \text {, } \\
\text { orally }\end{array}$ & $\begin{array}{l}\text { LT4, } 100 \mathrm{mcg} \text {, } \\
\text { orally }\end{array}$ \\
\hline TSH, mIU/L & $0.74(0.4-4.5)$ & & $1.52(0.3-4.7)$ & $<0.02(0.55-4.78)$ & $3.5(0.3-4.7)$ & $0.21(0.3-4.7)$ \\
\hline Free T4, ng/dL & $0.6(0.8-1.8)$ & & $0.4(0.8-1.6)$ & $0.7(0.89-1.76)$ & $0.6(0.8-1.6)$ & $0.7(0.8-1.6)$ \\
\hline $\begin{array}{l}\text { Total T4, } \\
\mathrm{mcg} / \mathrm{dL}\end{array}$ & & $4.0(4.5-12.0)$ & & $2.7(4.5-10.9)$ & & \\
\hline $\begin{array}{l}\text { Free T4 index, } \\
\mathrm{mcg} / \mathrm{dL}\end{array}$ & & $1.1(1.4-3.8)$ & & & & \\
\hline Free T3, pg/ml & $3.7(2.3-4.2)$ & & & & & $4.8(2.2-3.8)$ \\
\hline Total T3, ng/dL & & & $52(85-185)$ & & & \\
\hline $\begin{array}{l}\text { Reverse T3, } \\
\mathrm{ng} / \mathrm{dL}\end{array}$ & & & $12(8-25)$ & & & $7.3(9-27)$ \\
\hline
\end{tabular}

\section{Discussion}

This case is unique in that it shows, for the first time, that high T3 syndrome can occur in a patient with massive metastatic PTC or PDTC. Although high T3 syndrome has been found in about $20 \%$ patients with massive metastatic FTC, it has not been reported in patients with massive metastatic PTC, medullary thyroid cancer (MTC), or PDTC (3). FTC expresses high levels and activities of deiodinase 1 (D1) and 2 (D2), both converting T4 to T3, which explains the high T3 syndrome in patients with large burden of FTC $(3,4)$. It is not clear if the PTC, the PDTC, or both cause the high T3 syndrome in this patient. Classical and follicular variant of PTC can occasionally cause thyrotoxicosis so that they must be able to express D2 (the main enzyme that converts T4 into T3 in humans) at times; the free T4 and T3 levels are congruent in those cases, suggesting the D2 activity in PTC is usually not excessive(4-6). PDTC expresses lower levels of D2 than normal thyroid tissue or FTC, but expression of D1 is not studied in PDTC (7). It is thus possible 
that either PTC or PDTC expresses D2 or D1 which can convert endogenous or exogenous T4 to T3 if the tumor burden is large enough.

This case also highlights the importanceof recognizing high T3 syndrome. Had the high T3 syndrome been recognized when he had normal TSH during critical conditions, the inappropriate increase of LT4 dose couldhave been avoided. The eventual, albeit delayed, recognition ofhigh $\mathrm{T} 3$ syndrome also obviates the needs of expensive imaging of the pituitary. Clinical judgment can often reach a definitive thyroid function diagnosis in the face of incongruent test result (8). Assessment of T3 levels relative to T4 levels, however, is pivotal for recognizing high T3 syndrome, as shown in this case.

In summary, this novel case demonstrates that high T3 syndrome can also occur in a patient with PTC or PDTC. Additionally, the case illustrates the clinical relevance of recognizing this syndrome and the thyroid function test result profile leading to its diagnosis.

\section{REFERENCES}

[1] Dietrich JW, Landgrafe G, Fotiadou EH.TSH and thyrotropic agonists: key actors in thyroid homeostasis.J Thyroid Res. 2012;2012:351864.

[2] Friesema EC, Jansen J, Heuer H, Trajkovic M, Bauer K, Visser TJ.Mechanisms of disease: psychomotor retardation and high T3 levels caused by mutations in monocarboxylate transporter 8.Nat ClinPractEndocrinolMetab. 2006;2:512-23.
[3] Miyauchi A, Takamura Y, Ito Y, Miya A, Kobayashi $\mathrm{K}$, Matsuzuka F, et al.3,5,3'-Triiodothyronine thyrotoxicosis due to increased conversion of administered levothyroxine in patients with massive metastatic follicular thyroid carcinoma.J ClinEndocrinolMetab. 2008;93:2239-42.

[4] Gereben B, Zavacki AM, Ribich S, Kim BW, Huang SA, Simonides WS, et al.Cellular and molecular basis of deiodinase-regulated thyroid hormone signaling.Endocr Rev. 2008;29:898-938.

[5] Biyi A, Zaïmi S, Doudouh A.Functioning Metastases from Thyroid Papillary Carcinoma in Bone.J Nucl Med Technol. 2016;44:253-254.

[6] Gardner D, Ho SC.A rare cause of hyperthyroidism: functioning thyroid metastases.BMJ Case Rep. 2014;2014. pii: bcr2014206468.

[7] Makhlouf AM, Chitikova Z, Pusztaszeri M, Berczy M, Delucinge-Vivier C, Triponez F, et al.Identification of CHEK1, SLC26A4, c-KIT, TPO and TG as new biomarkers for human follicular thyroid carcinoma.Oncotarget. 2016; 7:45776-88.

[8] Koulouri O, Moran C, Halsall D, Chatterjee K, Gurnell M. Pitfalls in the measurement and interpretation of thyroid function tests.Best Pract Res ClinEndocrinolMetab. 2013;27:745-62.

Citation: Dr. Run Yu. High T3 Syndrome Associated with Metastatic Papillary and Poorly Differentiated Thyroid Cancer. Archives of Diabetes and Endocrine System. 2018; 1(1): 10-12

Copyright: (C) 2018 Dr. Run Yu. This is an open access article distributed under the Creative Commons Attribution License, which permits unrestricted use, distribution, and reproduction in any medium, provided the original work is properly cited. 